\title{
Redistribution and Internalization of Antibodies to Galactocerebroside by Oligodendroglia
}

\author{
Charissa A. Dyer and Joyce A. Benjamins \\ Department of Neurology, Wayne State University School of Medicine, Detroit, Michigan 48201
}

\begin{abstract}
Glial cultures from mouse brain were used to examine the direct interaction between oligodendroglia and antibodies to galactocerebroside (GaIC). The external surface of oligodendroglial membrane sheets showed large GaIC + patches separated by a GalC - network after exposure to anti-GalC and fluoresceinated second antibody at $37^{\circ} \mathrm{C}$. However, the membrane sheets were evenly stained when cultures were fixed prior to staining or stained at $0^{\circ} \mathrm{C}$. Further, exposure to second antibody at $0^{\circ} \mathrm{C}$ or to Fab tragments of second antibody at $37^{\circ} \mathrm{C}$ also gave even staining. These results indicate that GalC is normally distributed evenly on the surface of oligodendroglial membrane sheets, but that redistribution or patching of GalC:anti-GalC complexes occurs by crosslinking with second antibody at $37^{\circ} \mathrm{C}$. Antibodies to GalC are internalized rapidly and specifically by oligodendroglia. This process is temperature-dependent, and, in contrast to patching, does not require the presence of second antibody. Internalized antibodies are seen within $1 \mathrm{~min}$ throughout oligodendroglial membrane sheets, then aggregate in the sheets and in large vein-like structures leading to the cell body. By $1 \mathrm{hr}$, the cell body is densely packed with vesicles containing anti-GalC. By $24 \mathrm{hr}$ after a $10 \mathrm{~min}$ exposure to anti-GalC, internal antibody has disappeared. Anti-GalC is recycled to the cell surface within $5 \mathrm{~min}$ after exposure, and continues to appear on the surface for at least $4 \mathrm{hr}$ after the pulse.
\end{abstract}

This paper describes the interaction of antibodies with the glycolipid galactocerebroside (GalC), a specific marker for oligodendroglia. GalC is an important glycolipid initially expressed at the onset of myelination, and it is continually present in oligodendroglia that maintain myelin (Benjamins and Smith, 1984; Pfeiffer, 1984). We were interested in examining the effects of antibodies to GalC on oligodendrocytes in glial-enriched cultures from mouse brain for 2 reasons. First, the specific attach-

\footnotetext{
Received June 3, 1987; accepted Aug. 26, 1987.

This research was supported by NIH Grants NS 18898 and 13143 . We thank Dr. William Bartlett, Dr. Pamela Knapp, and Dr. Robert Skoff for their guidance in establishing glial cultures and methods for immunocytochemical staining in our laboratory, and for their discussion of the manuscript. We gratefully acknowledge Ms. Rose Callahan for technical assistance in performing ELISA assays and isolating IgG fractions, and Ms. Tracy Miele for secretarial assistance in preparing the manuscript. We thank Dr. Barbara Ranchst for providing the hybridoma line BR-D1, and Dr. Arthur McMorris and Mr. David Raible for providing antiserum to CNPase.

Correspondence should be addressed to Dr. Joyce Benjamins, Department of Neurology, Wayne State University School of Medicine, 540 E. Canfield Avenue, Detroit, MI 48201.

Abbreviations: FCS, fetal calf serum; GAM-TRITC, rhodamine-conjugated goat anti-mouse IgG.

Copyright (C) 1988 Society for Neuroscience $0270-6474 / 88 / 030883-09 \$ 02.00 / 0$
}

ment of macromolecules to cell-surface glycolipids has been shown to initiate mitogenic effects, morphogenesis, or differentiation (Sharon and Grant, 1978; Grant and Peters, 1979; Hakomori, 1981; Thompson and Tillack, 1985). Second, interaction of GalC with antibodies has been implicated as a key step in alteration of myelin in a number of systems.

With regard to the latter, antibodies to $\mathrm{GalC}$ in the presence of complement cause demyelination of organ cultures (Bornstein and Raine, 1970; Fry et al., 1987). Direct injection of sera containing antibodies to GalC into sciatic nerve or optic nerve causes rapid focal demyelination (Saida et al., 1979; Sergott et al., 1982). Thus, complement appears to be required for demyelination (Dorfman et al., 1979; Raine et al., 1981). Interestingly, antibodies to white matter (presumably to GalC) stimulate synthesis of GalC (Lehrer et al., 1979) and production of disorganized layers of membrane (Diaz et al., 1978) by oligodendroglia in organ culture. These results suggest that antibodies to GalC have direct, complement-independent effects on oligodendroglial metabolism and function. However, the mechanisms by which the antibodies produce these effects are not known.

Oligodendroglia grown in vitro elaborate processes and membrane sheets which contain GalC (Raff et al., 1978; Pfeiffer, 1984; Knapp et al., 1987a). These cultures provide an excellent system in which to examine the direct interaction between antibodies to GalC and individual oligodendroglia (Kachar et al., 1986). We have produced and characterized antisera against GalC that contain primarily IgG antibodies with specificity for GalC and the closely related glycolipid psychosine (Benjamins et al., 1987). This study characterizes the distribution and fate of these antibodies following their interaction with GalC on oligodendroglial cell bodies and membrane sheets. Immunocytochemical staining of oligodendroglia under a variety of conditions demonstrates that GalC has a generally uniform distribution across the surface of the membrane sheets, and binding of anti-GalC per se does not alter this distribution. However, addition of a second antibody directed against anti-GalC causes a distinctive redistribution, or patching, of the anti-GalC:GalC complexes, similar to the patching phenomenon observed in lymphocytes (Taylor et al., 1971). The anti-GalC:GalC complexes are rapidly endocytosed in vesicles that aggregate with time in the veins of the oligodendroglial membrane sheets and in the cell bodies. Internalization of the antibodies is a specific and rapid event, and does not require the presence of second antibody. Further, the antibodies are recycled back to the cell surface after internalization.

This is the first report of antibody-induced patching of an antigen on oligodendroglial membrane. Further, our findings are unique in that a surface glycolipid, rather than protein, me- 
diates the cellular responses leading to internalization and recycling of antibody.

\section{Materials and Methods}

Enriched oligodendrocyte cultures. Cultures were prepared according to the method of McCarthy and DeVellis (1980) as modified by Knapp et al. (1987a). Briefly, 2-4 d-old Balb/c or (Balb/c $\times$ SJL) F1 newborn mice were decapitated and their cerebra removed. The cerebra, while in DMEM (Gibco) plus $6.0 \mathrm{mg} \%$ glucose, were freed of meninges, sliced into small pieces, and then incubated for $30 \mathrm{~min}$ in $0.25 \%$ trypsin (Difco) and $10 \mu \mathrm{g} / \mathrm{ml}$ DNAase (Sigma). Cells were first dissociated in DMEM, $6.0 \mathrm{mg} \%$ glucose, $10 \%$ fetal calf serum (FCS), $50 \mu \mathrm{g} / \mathrm{ml}$ streptomycin, $50 \mu \mathrm{g} / \mathrm{ml}$ penicillin, and $0.15 \mu \mathrm{g} / \mathrm{ml}$ Fungizone by pipetting repeatedly through the small opening of a Pasteur pipette. The large pieces of debris were excluded from the cell suspension by filtering through a $130 \mu \mathrm{m}$ Nitex screen (Tetko, Elmsford, NY). The resulting dispersed cells were seeded at a density of $7 \times 10^{\circ}$ cells $/ 75 \mathrm{~cm}^{2}$ tissue culture flask (Corning) that had been precoated with $1 \mathrm{mg} / \mathrm{ml}$ poly-L-lysine (Sigma). After 8$11 \mathrm{~d}$ in vitro, the small, dark process-bearing cells were detached from the bed layer of astrocytes and other cells by shaking the flasks overnight at $37^{\circ} \mathrm{C}$ on a rotary shaker at $200 \mathrm{rpm}$. The floating cells were then washed, centrifuged, filtered through a $33 \mu \mathrm{m}$ Nitex screen, and incubated at $37^{\circ} \mathrm{C}$ for $20 \mathrm{~min}$ in an uncoated plastic petri dish to remove adherent flat cells. The remaining round floating cells were seeded at a density of $3.5 \times 10^{4}$ cells $/ 15$-mm-diameter poly-L-lysine-coated glass coverslip. Cells were grown in defined medium $(5 \mu \mathrm{g} / \mathrm{ml}$ bovine insulin, $50 \mu \mathrm{g} / \mathrm{ml}$ human transferrin, $30 \mathrm{~nm}$ sodium selenite, $10 \mathrm{ng} / \mathrm{ml}$ biotin) (Bottenstein, 1986) mixed with $1 / 2 \mathrm{vol}$ of the 10\% FCS-DMEM. The cultures were used in experiments at the age of $26 \mathrm{~d}$ after birth (22-24 $\mathrm{d}$ in vitro).

Antibodies. Polyclonal anti-GalC was produced in rabbits and characterized by Benjamins et al. (1987). The IgG fraction was purified from the sera by passage through a protein A-Sepharose 4B-CL column (Pharmacia) equilibrated in Tris-buffered saline (TBS), pH 7.4 (Ey et al., 1978). The unreactive material was washed through the column with TBS, $\mathrm{pH} 7.4$, the IgG was eluted with a $0.2 \mathrm{M}$ glycine buffer, $\mathrm{pH} 2.3$, and fractions were immediately neutralized with $0.5 \mathrm{M}$ Tris buffer, $\mathrm{pH}$ 8.5. Fractions containing protein (as determined by absorbance at 280 $\mathrm{nm}$ ) were pooled, lyophilized, and dialyzed against DMEM plus antibiotics, as above.

Hybridoma cell line BR-D1, which produces an IgG3 directed against GalC (Ranscht et al., 1982), was generously provided to us by Dr. Barbara Ranscht. The IgG fraction from the ascites was purified on a protein A-Sepharose 4B-CL column, lyophilized, and dialyzed as described for the polyclonal anti-GalC.

Polyclonal rabbit serum raised against $2^{\prime}, 3^{\prime}$-cyclic nucleotide phosphohydrolase (CNPase) (Ulmer et al., 1987) was generously donated by Dr. Arthur McMorris and David Raible. Since the serum was shown to contain antibodies reactive with proteolipid protein on immunoblots of mouse brain myelin (not shown), the serum was incubated overnight at $4^{\circ} \mathrm{C}$ with proteolipid protein bound to Sepharose $4 \mathrm{~B}-\mathrm{CL}$ (Pharmacia) in TBS, $\mathrm{pH}$ 7.4. The suspension was poured into a column, and the unbound material was washed through the column with TBS, pH 7.4. The remaining bound antibodies were eluted with $0.2 \mathrm{M}$ glycine, $\mathrm{pH}$ 2.3; fractions were neutralized with $0.5 \mathrm{M}$ Tris buffer, $\mathrm{pH} 8.5$. The antibodies that bound to the affinity column reacted with both proteolipid protein and CNPase on immunoblots of mouse CNS myelin. However, the nonadherent fraction reacted only with CNPase; this fraction was used to stain cultured cells.

The nonspecific rabbit and mouse IgG antibodies used as controls were also purified using protein A-Sepharose affinity chromatography as described above. Nonspecific rabbit IgG was isolated from bleeds taken prior to immunization with GalC. Murine IgG was isolated from Balb/c mice.

Immunolabeling. Cultures were incubated with $590 \mu \mathrm{g} / \mathrm{ml}$ of the IgG fraction from the rabbit antiserum to $\mathrm{GalC}$. This was equivalent to a 1:16 dilution of the original polyclonal anti-GalC serum. The amount of monoclonal anti-GaiC IgG used was an equivalent titer to that of a 1:16 dilution of the original polyclonal anti-GalC rabbit serum, as determined by ELISA (Benjamins et al., 1987). The nonspccific mousc and rabbit IgGs were also used at a concentration of $590 \mu \mathrm{g} / \mathrm{ml}$. Cultures were incubated at $37^{\circ} \mathrm{C}$ with rabbit IgG (either nonspecific or anti-GalC) for varying times, then labeled at 37 or $0^{\circ} \mathrm{C}$ for $30 \mathrm{~min}$ with fluoresceinconjugated goat anti-rabbit IgG (GAR-FITC) (Cappel) diluted at 1:100.
In some cases, cells were double-labeled with rhodamine-conjugated second antibody (GAR-TRITC). When cells were incubated with the monoclonal anti-GalC, they were stained at 37 or $0^{\circ} \mathrm{C}$ for 30 min with rhodamine-conjugated goat anti-mouse IgG (GAM-TRITC) (Pel-Freeze) at a dilution of 1:40. Cells were fixed for $10 \mathrm{~min}$ at room temperature with $4 \%$ formaldehyde prepared from paraformaldehyde. Cells labeled for CNPase were fixed, treated with $0.05 \%$ saponin for $10 \mathrm{~min}$, and then reacted with antibodies to $\mathrm{CNPase}$. Internalized anti-GalC was visualized by exposing cultures to anti-GalC, fixing the cells, and blocking the externally bound anti-GalC with goat anti-rabbit IgG. Cultures were then exposed to $0.05 \%$ saponin and stained with fluorescein-conjugated second antibodies. In this way, internal anti-GalC antibodies that were not accessible to the blocking second antibodies prior to saponin treatment were exposed and labeled with fluorescein-conjugated second antibodies. All preparations were viewed on a Leitz Laborlux 12 microscope equipped with appropriate filters for rhodamine and fluorescein optics, and photographed with 400 ASA film.

\section{Results}

Distribution of galactocerebroside on the surface of oligodendroglial membrane sheets

The surface distribution of GalC on oligodendroglial membrane sheets was examined initially by staining live shakeoff cultures with anti-GalC and fluoresceinated second antibodies at $37^{\circ} \mathrm{C}$, followed by fixation (Knapp et al., 1987a). Under these conditions, a distinctive patchy pattern was apparent on the surface of virtually all oligodendroglial membrane sheets (Fig. 1a). In contrast, the membrane sheets showed a generally even pattern of staining when cultures were fixed and subsequently stained for GalC (Fig. $1 b$ ) or stained for GalC at $0^{\circ} \mathrm{C}$ and then fixed (Fig. 1c). Thus, fixation per se does not give rise to the patching, and the appearance of this pattern is temperature-dependent. These results further indicate that the distribution of GalC on the membrane sheets of oligodendroglia in culture is even rather than patched.

\section{Internal distribution of galactocerebroside}

Fixation of cells with $4 \%$ formaldehyde is frequently used to expose internal antigens in order to allow immunocytochemical staining. The observation that the membrane sheets showed a similar fluorescent pattern whether cells were fixed and then stained with anti-GalC (Fig. $1 b$ ) or stained live at $0^{\circ} \mathrm{C}$ and then fixed (Fig. 1c) suggested that fixation was not exposing internal GalC. To investigate this possibility, we compared the staining of GalC with that of the internal antigen CNPase following fixation with formaldehyde, or fixation plus exposure to $0.05 \%$ saponin to permeabilize the membranes. No staining of CNPase in membrane sheets was observed after fixation alone (Fig. $2 a$ ). However, fixation plus saponin revealed an elaborate pattern of staining in the sheets (Fig. $2 b$ ), as described by Knapp et al. (1987b). Under both of these conditions the cell bodies were stained, although more intensely after exposure to saponin. With anti-GalC, the membrane sheets appeared evenly stained following fixation alone, as shown in Figure $1 b$. After fixation plus saponin, a different pattern was observed, with vein-like structures and aggregates of GalC stained throughout the sheets (Fig. $2 c$ ). Further, the difference between external and internal $\mathrm{GalC}$ distribution was clearly demonstrated by double-labeling cells for external and internal GalC. First, external GalC was labeled with the rabbit polyclonal anti-GalC IgG and fluorescein-conjugated second antibody at $0^{\circ} \mathrm{C}$. Cells were then fixed, their membranes permeabilized with saponin, and internal GalC visualized with the murine monoclonal anti-GalC IgG and rhodamine-conjugated second antibody. Figure $2 d$ shows the gen- 

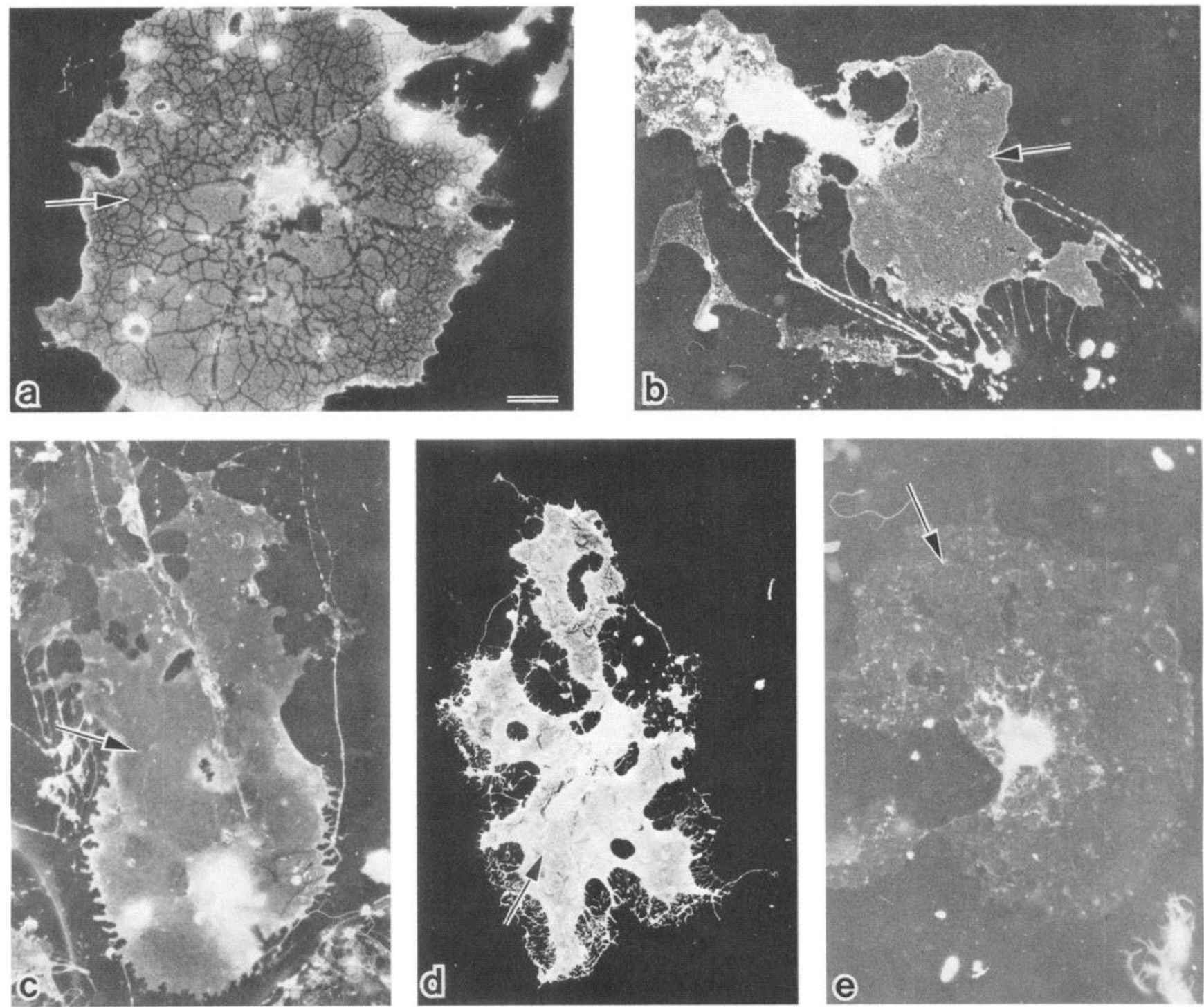

Figure 1. Surface distribution of rabbit anti-GalC IgG on membrane sheets of cultured oligodendrocytes. $a$, Patchy staining pattern (arrow) following incubation with anti-GalC for $10 \mathrm{~min}$ at $37^{\circ} \mathrm{C}$ and GAR-FITC for $30 \mathrm{~min}$ at $37^{\circ} \mathrm{C}$. $b$, Uniform staining of membrane sheets (arrow) with anti-GalC and GAR-FITC after fixing with $4 \%$ paraformaldehyde. $c$, Solid staining of membrane sheet (arrow) with anti-GalC at $0^{\circ} \mathrm{C}$ for 10 min followed by GAR-FITC at $0^{\circ} \mathrm{C}$ for $30 \mathrm{~min}$ and then fixation. Solid staining of sheets (arrows) after incubating with anti-GalC for 10 min followed by either $(d)$ GAR-FITC at $0^{\circ} \mathrm{C}$ for $30 \mathrm{~min}$ and fixation or $(e)$ the Fab fragment of GAR-FITC at $37^{\circ} \mathrm{C}$ for $30 \mathrm{~min}$ and fixation. Bar, $20 \mu \mathrm{m}$.

erally uniform staining of surface GalC on an oligodendroglial membrane sheet, while Figure $2 e$ demonstrates the internal GalC distribution in that same sheet. The internal GalC is present in small blebs throughout the sheets and in veins running through these sheets. Thus, fixation alone is not adequate to allow exposure of the internal CNPase and GalC in these membrane sheets.

\section{Patching of galactocerebroside: antibody complexes on} membrane sheets is due to cross-linking by second antibody

Since patching on oligodendroglial membranes was shown to result from interaction with $\mathrm{GalC}$ antibodies and not from fixation, it was important to determine whether it was due directly to binding of the primary antibodies (anti-GalC) or to crosslinking of the anti-GalC:GalC complexes by the fluoresceinated second antibodies. Three conditions were employed to determine whether anti-GalC per se caused patching of GalC in the membrane sheets. Cultures were incubated with anti-GalC at $37^{\circ} \mathrm{C}$ for $10 \mathrm{~min}$ as described above. One set of cultures was then exposed to fluoresceinated second antibodies at $0^{\circ} \mathrm{C}$ (Fig. $1 d$ ), while another set of cultures was fixed with formaldehyde prior to the addition of second antibodies (not shown). In both cases, membrane sheets showed a uniform pattern of staining. Thus, patching requires the presence of second antibody on unfixed membranes, and the process is temperature-dependent. A third set of cultures was incubated at $37^{\circ} \mathrm{C}$ with anti-GalC, then with fluoresceinated monovalent Fab fragments, rather than with the bivalent IgG second antibodies (Fig. 1e). Although the membrane sheets were less intensely stained with the Fab fragments, no patching was observed. These results indicate that cross-linking of GalC:anti-GalC complexes with bivalent second antibody is required for patching to occur. The same series of experiments was repeated with monoclonal antibodies to GalC; the results were identical to those obtained with the polyclonal 

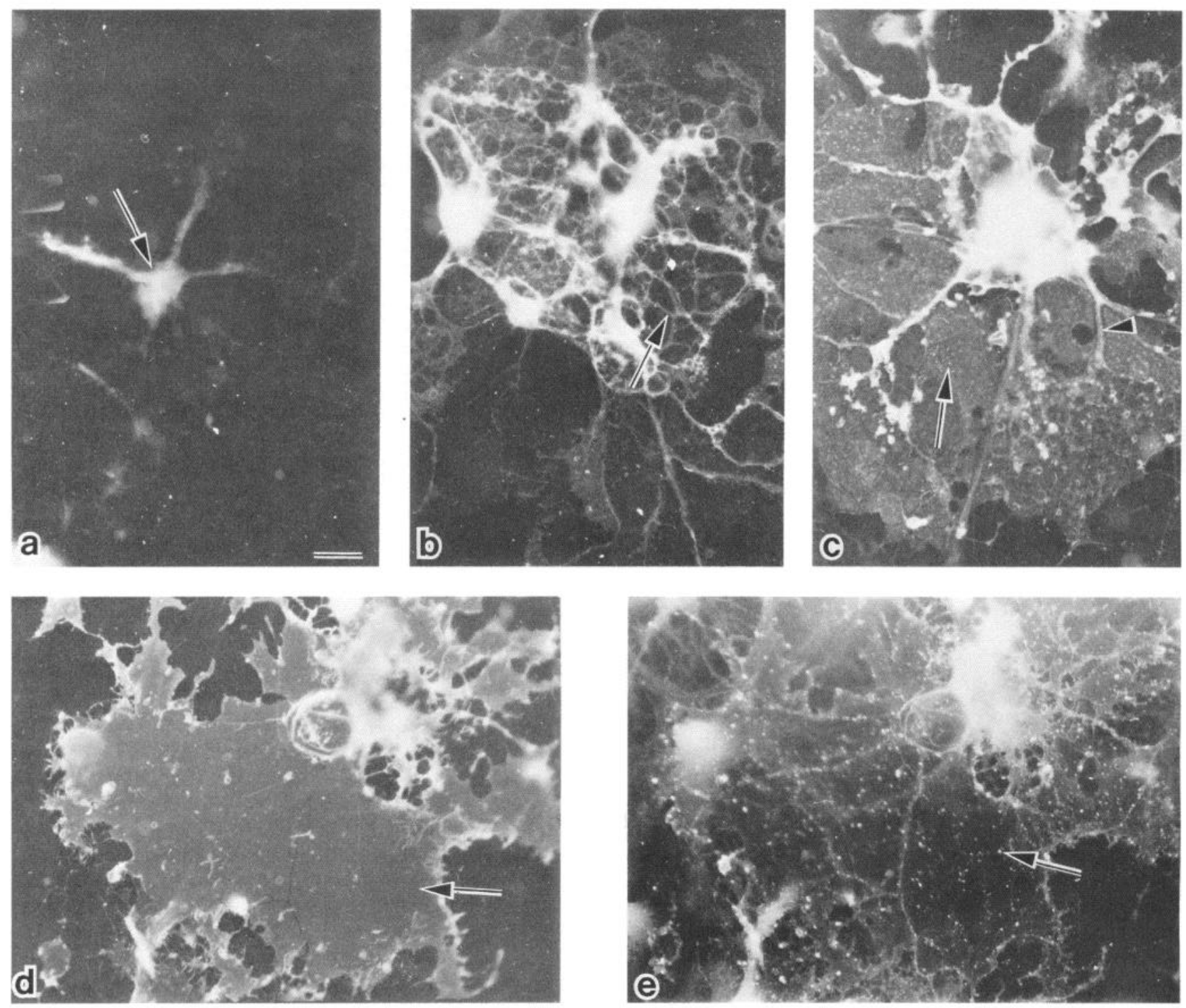

Figure 2. Effects of fixation and subsequent treatment with saponin on the visualization of GalC and CNPase. $a$, Oligodendroglial cell body (arrow) stained with anti-CNPase after fixation; note absence of staining in sheets. $b$, Structures in sheets (arrow) and cell bodies stained with antiCNPase following fixation and saponin treatment. $c$, Vein-like structures (arrowhead) and blebs (arrow) of staining observed in oligodendrocyte following fixation, exposure to saponin, and addition of anti-GalC and second antibody. $d$, Solid surface staining of an oligodendrocyte (arrow) after exposure to rabbit anti-GalC and GAR-FITC at $0^{\circ} \mathrm{C} . e$, Blebs of internal GalC (arrow) detected throughout the membrane sheet and in the veins of the same cell shown in $d$ after surface staining, fixation, saponin treatment, and addition of monoclonal anti-GalC and GAM-TRITC. Bar, $20 \mu \mathrm{m}$.

antibodies, confirming that the patching is due to redistribution of $\mathrm{GalC}$ rather than to some other membrane component.

\section{Antibodies to GalC are internalized by oligodendroglia}

Antibodies to $\mathrm{GalC}$ were internalized specifically by cells identified as oligodendroglia on the basis of immunocytochemical staining for GalC and CNPase (not shown in all cases). In these experiments, cultures were cooled for $15 \mathrm{~min}$ on ice, then incubated at $0^{\circ} \mathrm{C}$ for $15 \mathrm{~min}$ in the presence of anti-GalC to allow binding of antibodies. The cultures were then placed in medium with anti-GalC at $37^{\circ} \mathrm{C}$ and stained for internal anti-GalC at various times, as described in Materials and Methods.

At zero time, little internal fluorescence was detected (Fig. $3 a$ ). However, by 1 min fluorescent vesicles were observed throughout membrane sheets, and aggregates of vesicles were apparent by $5 \mathrm{~min}$ (Fig. $3 b$ ). Major veins, as well as the cell bodies, were packed with vesicles by $30 \mathrm{~min}$, with an even greater number of vesicles containing anti-GalC visible by $1 \mathrm{hr}$ (Fig. 3c). Most of the fluorescence was present near the cell body with some vesicles in processes. Thus, with time, the number of fluorescent vesicles increased, as did the intensity of staining. Vesicles appeared stacked on top of one another, giving a 3 -dimensional effect. This was in contrast to the relatively uniform staining of external anti-GalC on the same cell (Fig. 3d). These results demonstrate 2 points: (1) the staining of external anti-GalC is distinctly different from that of internalized anti$\mathrm{GalC}$, and (2) even after $1 \mathrm{hr}$ of continuous exposure to anti$\mathrm{GalC}$ the surface of the oligodendroglial membrane is not depleted of GalC but is solidly stained. Internalized immunoglobulins were not detected in oligodendroglia upon incubation 

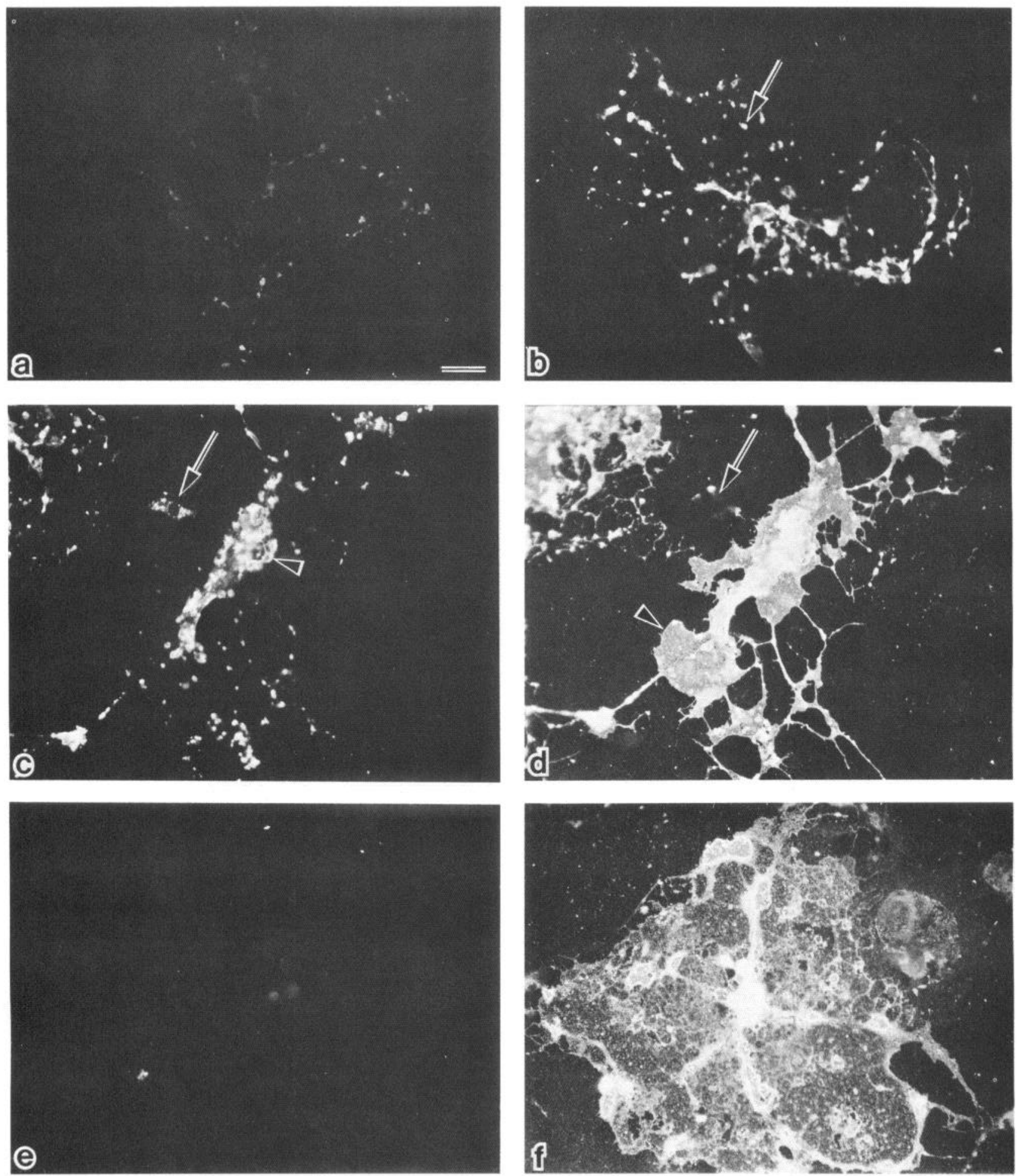

Figure 3. Antibodies to GalC internalized rapidly and specifically by oligodendrocytes. $a$, No staining of internalized anti-GalC at the end of the 15 min exposure to anti-GalC at $0^{\circ} \mathrm{C}$ (zero time point). $b$, Membrane sheet with internal vesicles (arrow) containing anti-GalC after a 5 min exposure to antibody at $37^{\circ} \mathrm{C}$. $c$, Cell body loaded with vesicles (arrowhead) containing anti-GalC after $1 \mathrm{hr}$ incubation with antibody at $37^{\circ} \mathrm{C}$ and stained with GAR-TRITC. Small cell presumed to be a microglia containing internalized IgG at arrow. $d$, Solid surface staining (arrowhead) of anti-GalC with GAR-FITC on the same oligodendrocyte shown in $c$; note lack of surface staining of microglia (arrow). $e$, No internalized IgG detected in oligodendroglia incubated $1 \mathrm{hr}$ at $37^{\circ} \mathrm{C}$ with nonspecific rabbit IgG. $f$, The same cell as in $e$, labeled with anti-CNPase. Bar, 20 $\mu \mathrm{m}$.

of cultures with control IgG for these time periods (Fig. 3, $e, f$ ). Small cells that may be microglia internalize IgG within $1 \mathrm{hr}$ of exposure to either nonspecific IgG or to anti-GalC IgG, presumably via Fc receptors. This cell type is demonstrated in
Figure $3 c$; a small cell to the upper left side of the oligodendrocyte is brightly stained for internal IgG. This cell is not detected by surface staining for GalC, as is shown in Figure $3 d$.

These experiments demonstrate that antibodies to GalC are 

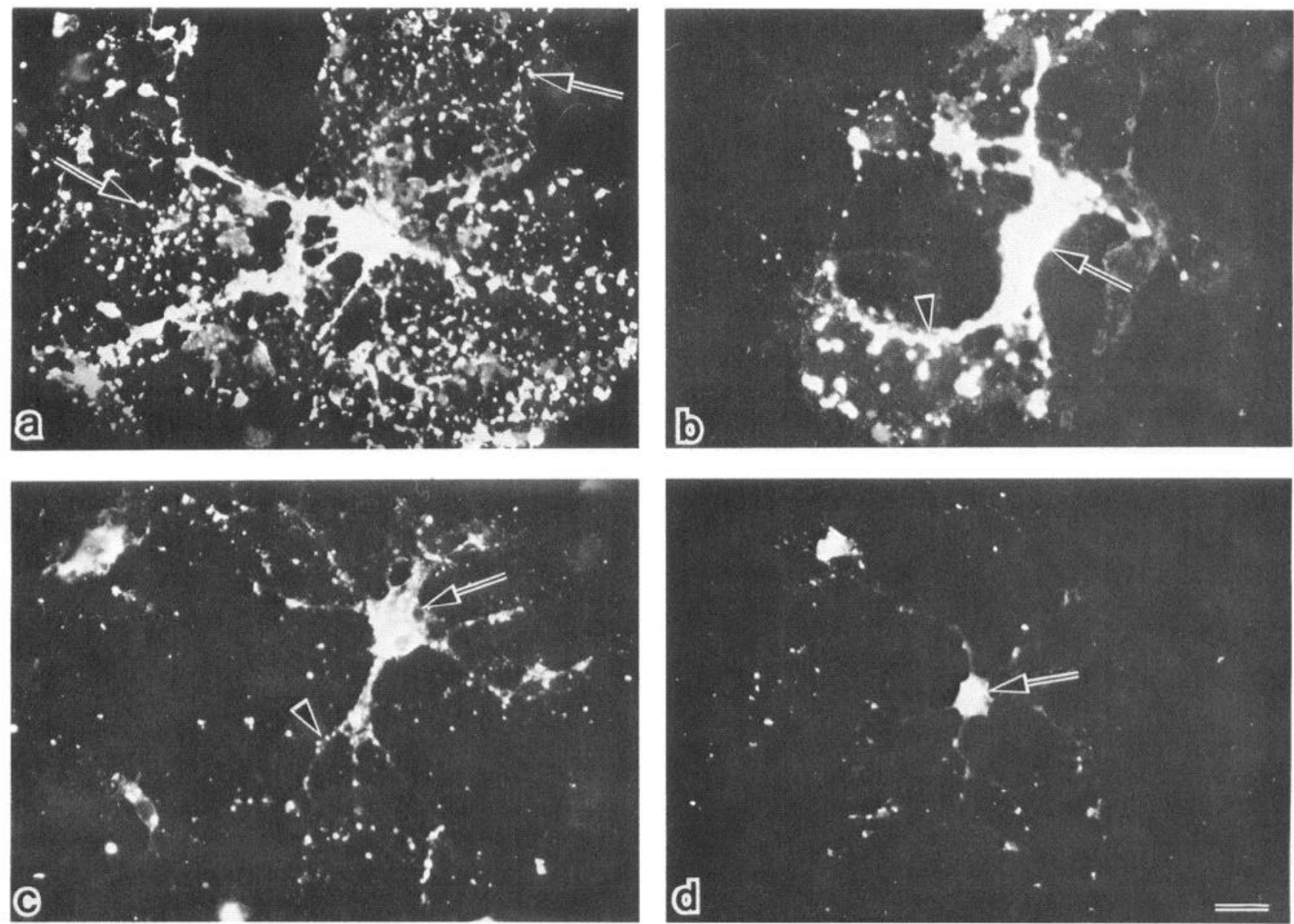

Figure 4. Distribution of anti-GalC following a 10 min pulse. $a$, Internal vesicles loaded with anti-GalC (arrows) detected throughout membrane sheet $1 \mathrm{~min}$ after pulse. $b$, Migration of vesicles through veins (arrowhead) to the cell body (arrow) by 5 min following the pulse. $c$, Six hours after the pulse, few vesicles remain in the veins (arrowhead) or cell body (arrow). $d$, At $24 \mathrm{hr}$ following the pulse, faint fluorescence in the cell body (arrow), with virtually no fluorescent vesicles observed in veins or membrane sheets. Bar, $20 \mu \mathrm{m}$.

internalized rapidly and specifically by oligodendroglia, and that second antibody is not required for internalization to occur. Further, the process is temperature-dependent, since virtually no internalized antibodies were seen after $15 \mathrm{~min}$ exposure to anti-GalC at $0^{\circ} \mathrm{C}$ (Fig. $3 a$ ).

\section{Fate of internalized anti-GalC following $10 \mathrm{~min}$ pulse}

Anti-GaiC was incubated with cultures for $10 \mathrm{~min}$, then removed, and the pulse of internalized antibodies was followed to determine its fate with time. Cells were prechilled and exposed to anti-GalC at $0^{\circ} \mathrm{C}$ as previously described, then placed in medium with anti-GalC at $37^{\circ} \mathrm{C}$. After $10 \mathrm{~min}$ at $37^{\circ} \mathrm{C}$, the anti-GalC medium was removed, the cells were washed, and fresh medium without antibodies was added. At 1 min after removal of antibodies, internal fluorescent vesicles were observed throughout the membrane sheets (Fig. 4a). By 5 min following the pulse, these vesicles appeared to aggregate in the sheets and in the major vein-like structures leading to the cell bodies, as well as in the cell bodies (Fig. $4 b$ ). By $1 \mathrm{hr}$ the cell bodies were densely packed with these vesicles. After $6 \mathrm{hr}$, fluorescence was observed in the cell bodies and in the major veinlike structures in the sheets. However, the number of vesicles was greatly diminished (Fig. $4 c$ ). By $24 \mathrm{hr}$ the cell bodies and vein-like structures were weakly stained, and vesicles were not apparent (Fig. 4d). Incubation with prebleed $\mathrm{IgG}$ for $10 \mathrm{~min}$ instead of anti-GalC showed no fluorescent internal vesicles. Again, similar results were obtained with monoclonal antibody to GalC.

\section{Antibodies to galactocerebroside are recycled to the cell surface following internalization}

The disappearance of internalized anti-GalC demonstrated in the pulse experiment prompted us to examine whether antibodies were being recycled to the cell surface. Cultures were pulsed with anti-GalC for $10 \mathrm{~min}$ following prechilling and exposure to anti-GalC at $0^{\circ} \mathrm{C}$. After extensive washing to remove excess anti-GalC, cells were incubated without antibodies for up to $4 \mathrm{hr}$. At various times after the pulse, the $\mathrm{F}\left(\mathrm{ab}^{\prime}\right)_{2}$ fragment of fluorescein-conjugated second antibody (anti- $\gamma$ chain) was then applied to cultures for $30 \mathrm{~min}$ at $0^{\circ} \mathrm{C}$. $\mathrm{F}\left(\mathrm{ab}^{\prime}\right)_{2}$ fragments were used to ensure that staining was due only to recycled antiGalC and not to binding of second antibody to Fc receptors. Control cultures were treated as above, except that the $10 \mathrm{~min}$ pulse with anti-GalC was at $0^{\circ} \mathrm{C}$ instead of $37^{\circ} \mathrm{C}$. In another set of controls, cultures were exposed for $10 \mathrm{~min}$ at $37^{\circ} \mathrm{C}$ to nonspecific rabbit IgG instead of to anti-GalC.

A direct comparison was made of those cultures that internalized antibodies at $37^{\circ} \mathrm{C}$ for $10 \mathrm{~min}$ with those that were exposed to antibodies at $0^{\circ} \mathrm{C}$ and did not internalize antibodies. Cultures exposed to anti-GalC were washed and placed in fresh 

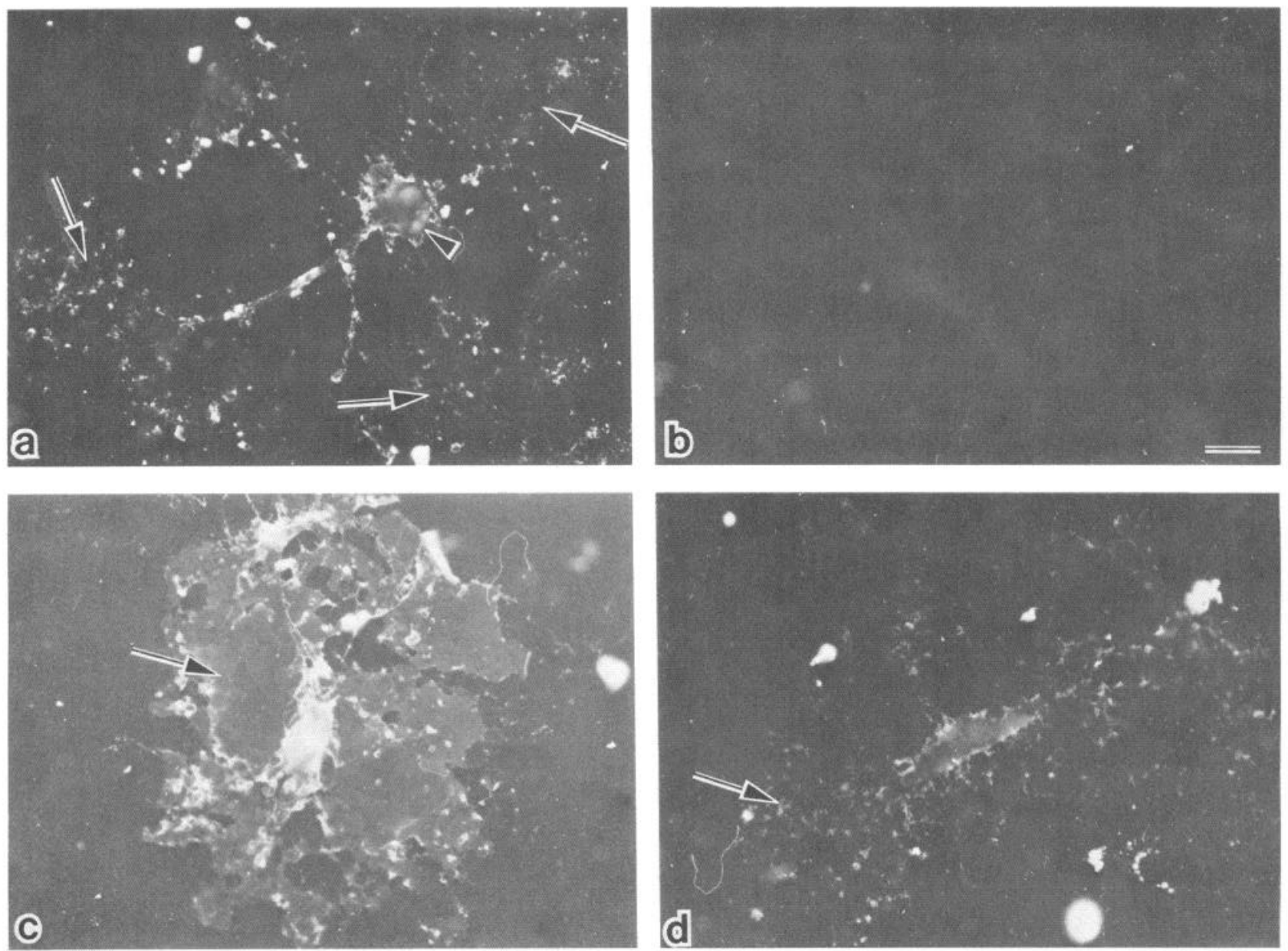

Figure 5. Recycling of internalized anti-GalC to the oligodendroglial cell surface. $a$, Anti-GalC visible on the surface of an oligodendroglial cell body (arrowhead), processes, and membrane sheets (arrows) $4 \mathrm{hr}$ after the pulse at $37^{\circ} \mathrm{C}$. $b$, No surface staining of oligodendrocytes in control cultures exposed to anti-GalC at $0^{\circ} \mathrm{C}$. $c$. Solid staining of surface of oligodendroglial cell body and membrane sheet (arrow) after pulse with anti$\mathrm{GalC}$ at $37^{\circ} \mathrm{C}$, followed by continuous exposure to fluoresceinated $\mathrm{F}\left(\mathrm{ab}^{\prime}\right)_{2}$ second antibody for $4 \mathrm{hr}$. $d$, Faint fluorescence on membrane surface of oligodendrocyte (arrow) in control culture after exposure to anti-GalC at $0^{\circ} \mathrm{C}$, followed by staining with $\mathrm{F}\left(\mathrm{ab}^{\prime}\right)_{2}$ second antibody, as in $c$. Bar, 20 $\mu \mathrm{m}$.

medium with no antibodies; under these conditions, anti-GalC dissociated from the cell surface within 5 min (results not shown). As early as $5 \mathrm{~min}$ after the pulse at $37^{\circ} \mathrm{C}$, oligodendroglia had detectable fluorescence on the surface of the cell bodies (not shown). Figure $5 a$ demonstrates the anti-GalC present on the cell surface of an oligodendroglia $4 \mathrm{hr}$ after previous exposure to anti-GalC for $10 \mathrm{~min}$ at $37^{\circ} \mathrm{C}$. Typically, the surface of the cell body is brightly stained, with dimly stained sheets. No surface fluorescence was observed in cultures exposed to anti-GalC at $0^{\circ} \mathrm{C}$ (Fig. $5 b$ ) or in cultures incubated with nonspecific rabbit IgG. When cultures were incubated continuously for $4 \mathrm{hr}$ in the presence of fluoresceinated $\mathrm{F}\left(\mathrm{ab}^{\prime}\right)_{2}$ second antibody following the pulse with anti-GalC at $37^{\circ} \mathrm{C}$, cell bodies and sheets were brilliantly stained (Fig. $5 c$ ) compared to those pulsed at $0^{\circ} \mathrm{C}$ (Fig. $5 d$ ). Thus it appears that once antibodies are recycled to the cell surface, they dissociate unless second antibodies bind and, presumably through cross-linking, trap the anti-GalC on the cell surface.

\section{Discussion}

We have demonstrated 2 independent events following binding of antibodies to the glycolipid GalC on oligodendroglial mem- brane sheets. One is the redistribution of anti-GalC: $\mathrm{GalC}$ into patches upon cross-linking by a second antibody at $37^{\circ} \mathrm{C}$, and the second is the rapid internalization of anti-GalC:GalC complexes. The conclusion that these are independent events arises from the observation that patching requires the presence of second antibody, while internalization does not. The separation of these 2 cellular events, patching and internalization of ligand: receptor complexes, has also been demonstrated in a previous study of Con A binding to Chinese Hamster ovary cells (CHO) (Storrie and Edelson, 1977). CHO cells rapidly endocytosed the lectin bound to cell-surface molecules in a random manner without any intermediate stage of surface redistribution. The rapid internalization of anti-GalC:GalC complexes and of Con A: receptor complexes without previous surface redistribution is in contrast to the sequence of events that occurs on lymphocytes after the binding of ligands. For many ligand:receptor complexes, patching and capping occur first, followed by endocytosis (Taylor et al., 1971; Sedlacek et al., 1976; Sela et al., 1978; Geiger and Singer, 1979).

The factors regulating redistribution versus endocytosis upon binding of a ligand have not been clearly defined. Storrie and Edelson (1977) suggested that the extent of redistribution of 
receptor and subsequent capping may reflect a competition between aggregation in the plane of the membrane and endocytosis of the bound ligand. They postulated that capping may be a characteristic process of cells such as lymphocytes, with very low endocytic rates, whereas cells such as macrophages, with high endocytic rates, might not be expected to show capping. Our results indicate that oligodendroglia have high endocytic rates, with membrane properties more like thosc of macrophages than of lymphocytes. Interestingly, Triarhou et al. (1985) have recently described active phagocytosis by oligodendroglia.

The mechanism underlying the patching of the GalC:antiGalC:second antibody complexes on oligodendroglial membranes is as yet unknown, although we have shown it to be temperature-dependent. One possibility is that redistribution may be due to lateral phase separation of the cross-linked immunocomplexes, as described in studies showing that cytoskeleton is not involved in the redistribution of haptenated lipids in lymphocytes (Schroit and Pagano, 1978; Spiegel et al., 1984). On the other hand, the patching may be an energy-dependent process that is linked to cytoskeleton, as in the case of cholera toxin binding to the ganglioside GM1 after cross-linking by a second agent (Craig and Cuatrecasas, 1975; Revesz and Greaves, 1975; Kellie et al., 1983; Spiegel et al., 1984). Further experiments are required to distinguish between these 2 mechanisms.

Redistribution of GalC does not occur after interaction with anti-GalC alone, indicating that $\mathrm{GalC}$ is a monovalent lipid antigen. GalC is distributed uniformly throughout membrane sheets, and the presence of the bivalent anti-GalC IgG at $37^{\circ} \mathrm{C}$ does not alter its distribution. Redistribution of GalC does not occur when cultures are incubated with anti-GalC followed by the Fab fragment of second antibody at $37^{\circ} \mathrm{C}$ for $30 \mathrm{~min}$. Thus, patching occurs only when bivalent second antibody is added at $37^{\circ} \mathrm{C}$ subsequent to anti-GalC. Stern and Bretscher (1979) have previously reported similar results with mouse thymocytes and several tumor lines. There was no redistribution after the binding of antibodies to the Forssman glycolipid unless second antibody was present. Because of this, they concluded that the pentasaccharide head group of this glycolipid is monovalent. Therefore, once an antibody is bound to the glycolipid, it is sterically impossible for another antibody molecule to interact with the pentasaccharide. Not only does this limit the binding of more than one antibody to each head group, but once antibody is bound, the head group would also be restricted from binding to transmembrane proteins linked to cytoskeleton (Stern and Bretscher, 1979). Thus, redistribution via association with the cytoskeleton would be impossible. In analogy to the above case, once antibody is bound to $\mathrm{GalC}$, which has a single galactose head group, it may be physically impossible for it to associate with any other molecules.

Patching of monovalent lipids by primary antibodies alone has been reported in other systems (Schroit and Pagano, 1978; Stern and Bretscher, 1979). One mechanism proposed to explain this phenomenon is that the monovalent lipids exist as microaggregates that behave as multivalent antigens. The crosslinking of many microaggregates by the bivalent antihapten antibodies would then result in patching. This, however, is not observed when anti-GalC interacts with GalC on oligodendroglial membranes, and therefore it is unlikely that GalC exists as microaggregates. Our results demonstrate that cross-linking of $2 \mathrm{GalC}$ molecules by individual bivalent antibodies does not cause patching, but does cause the internalization of these complexes.
Binding of $\mathrm{IgG}$ molecules to GalC on oligodendroglial membranes is followed by rapid endocytosis. This process was shown to be specific and temperature-dependent. The presence of second antibody was also demonstrated not to be necessary for internalization. Indeed, after $1 \mathrm{~min}$ of exposure to anti-GalC, vesicles containing anti-GalC are detected throughout the membrane sheets. The mechanism of endocytosis of bivalent antibodics, cach presumably bound to 2 lipid molecules, is unknown. However, Hart et al. (1985) have shown that the binding of antibodies to TNP-conjugated lipids causes a decrease in membrane fluidity. The effect of antibody was observed first on the surface of bilayer membranes and then migrated the length of the lipid chains to their terminal methyl groups. This effect was complete by $40 \mathrm{sec}$ at $25^{\circ} \mathrm{C}$. Thus, it may be possible that physical changes in the membrane signal events such as the internalization of anti-GalC:GalC complexes.

Another interesting result is that GalC is not depleted from oligodendroglial membranes even after $1 \mathrm{hr}$ of continuous internalization in the presence of anti-GalC. This may be due in part to the rapid recycling of anti-GalC:GalC complexes back to the cell surface after internalization. Similar results demonstrating the recycling of an antibody to a lipid on a toad kidney epithelial cell line have been reported (Turner et al., 1985). Also, the existence of nonacidic endosomes that allow ligand:receptor complexes to remain associated until they are reinserted into the plasma membrane has been demonstrated (Wileman et al., 1985). It is possible then, that anti-GalC remains bound to GalC after internalization until it is recycled back to the cell surface.

Increased production of $\mathrm{GalC}$ has been shown in myelinating organ cultures after interaction with antibodies to white matter (Lehrer et al., 1979). In addition to the recycling of anti-GalC presumably still bound to $\mathrm{GalC}$, it is possible that the synthesis of GalC is increased, which might also account for the continuous presence of surface GalC despite its internalization.

Anti-GalC induces several changes in oligodendroglial membranes - redistribution of GalC, internalization of antibody: GalC in vesicles, and recycling of antibody to the cell surface. Cytoskeletal and metabolic alterations accompanying these changes are under investigation. Future studies will examine whether internalization of antibodies to GalC stimulates mitogenesis or maturation of oligodenroglia. The effects of antibodies to other glycolipids and to myelin proteins will be compared with those of anti-GalC to assess whether the responses are unique for GalC or shared by other molecules in the oligodendroglial plasma membrane. These responses of oligodendroglia to anti-GalC provide models for responses of these cells to natural ligands during development, and to antibodies during immune-mediated demyelination.

Note added in proof: After acceptance of this paper, Ranscht et al. (1987) reported that interaction of anti-GalC with Schwann cells results in loss of GalC from membrane surfaces and prevents myelination.

\section{References}

Benjamins, J. A., and M. E. Smith (1984) Metabolism of myelin. In Myelin, 2nd Ed., P. Morrell, ed., pp. 225-258, Plenum, New York. Benjamins, J. A., R. E. Callahan, I. Montgomery, D. M. Studzinski, and C. A. Dyer (1987) Production and characterization of high titer polyclonal antibodies to galactocerebroside. J. Neuroimmunol. 14: 325-338.

Bornstein, M. B., and C. S. Raine (1970) Experimental allergic en- 
cephalomyelitis antiserum inhibition of myelination in vitro. Lab. Invest. 23: 536-542.

Bottenstein, J. E. (1986) Growth requirements in vitro of oligodendrocyte cell lines and neonatal rat brain oligodendrocytes. Proc. Natl. Acad. Sci. USA 83: 1955-1959.

Craig, S. W., and P. Cuatrecasas (1975) Mobility of cholera toxin receptors on rat lymphocyte membranes. Proc. Natl. Acad. Sci. USA 72: 3844-3848.

Diaz, M., M. B. Bornstein, and C. J. Raine (1978) Disorganization of myelinogenesis in tissue culture by anti-CNS antiserum. Brain Res. 154: 231-239.

Dorfman, S. J., J. M. Fry, and D. Silberberg (1979) Antiserum induced myelination inhibition in vitro without complement. Brain Res. 177: 105-114.

Ey, P. L., S. J. Prowse, and C. R. Jenkin (1978) Isolation of pure IgG1, IgG2a and IgG2b immunoglobulins from mouse serum using protein A-Sepharose. Immunochemistry 15: 429-436.

Fry, J. M., S. Weissbarth, G. M. Lehrer, and M. B. Bornstein (1987) Cerebroside antibody inhibits sulfatide synthesis and myelination and demyelination in cord tissue cultures. Science 183: 540-542.

Geiger, B., and S. J. Singer (1979) The participation of $\alpha$-actinin in the capping of cell membrane components. Cell 16: 213-222.

Grant, C. W. M., and M. W. Peters (1979) Lectin-membrane interactions. Information from model systems. Biochim. Biophys. Acta 779: 403-422.

Hakomori, S. (1981) Glycosphingolipids in cellular interaction, differentiation and oncogenesis. Annu. Rev. Biochem. 50: 733-764.

Hart, M. J., K. Kimura, and M. Nakanishi (1985) Selected positions of acyl chains are affected differently by antibody which results in decreased membrane fluidity. Fed. Eur. Biochem. Soc. 190: 249-252.

Kachar, B., T. Behar, and M. Dubois-Dalcq (1986) Cell shape and motility of oligodendrocytes cultured without neurons. Cell Tissue Res. 244: 27-38

Kellie, S., B. Patel, E. J. Pierce, and D. R. Critchley (1983) Capping of cholera toxin-ganglioside GM1 complexes on mouse lymphocytes is accompanied by co-capping of $\alpha$-actinin. J. Cell Biol. 97: 447-454.

Knapp, P. E., W. P. Bartlett, and R. P. Skoff (1987a) Cultured oligodendrocytes mimic in vivo phenotypic characteristics: cell shape, expression of myelin specific antigens and membrane production. Dev. Biol. 120: 356-365.

Knapp, P. E., R. P. Skoff, and T. J. Sprinkle (1987b) Oligodendrocyte development in vitro: Double-label immunostaining for galactocerebroside and $2^{\prime}, 3^{\prime}$-cyclic nuclcotide- $3^{\prime}$-phosphohydrolase. J. Neurochem. 485: 530 .

Lehrer, G. M., S. Maker, D. J. Silides, C. Weiss, and M. B. Bornstein (1979) Stimulation of myelin lipid synthesis in vitro by white matter antiserum in absence of complement. Brain Res. 172: 557-560.

McCarthy, K. D., and J. DeVellis (1980) Preparation of separate astroglial and oligodendroglial cell cultures from rat cerebral tissue. J. Cell Biol. 85: 890-902.

Pfeiffer, S. E. (1984) Oligodendrocyte development in culture systems. In Oligodendroglia, W. T. Norton, ed., pp. 233-298, Plenum, New York.

Raff, M. C., R. Mirsky, K. L. Fields, R. P. Lisak, S. H. Dorfman, D. H. Silbergerg, N. A. Gregson, S. Leibowitz, and M. C. Kennedy (1978) Galactocerebroside is a specific cell-surface antigenic marker for oligodendrocytes in culture. Nature 274: 813-816.

Raine, C. S., A. B. Johnson, D. M. Marcus, A. Suzuki, and M. B.
Bornstein (1981) Demyelination in vitro. Absorption studies demonstrate that galactocerebroside is a major target. J. Neurol. Sci. 52: 117-131.

Ranscht, B., P. A. Clapshaw, J. Price, M. Noble, and W. Seifert (1982) Development of oligodendrocytes and Schwann cells studied with a monoclonal antibody against galactocerebroside. Proc. Natl. Acad. Sci. USA 79: 2709-2713.

Ranscht, B., P. M. Wood, and R. P. Bunge (1987) Inhibition of in vitro peripheral myelin formation by monoclonal anti-galactocerebroside. J. Neurosci. 7: 2936-2947.

Revesz, T., and M. Greaves (1975) Ligand-induced redistribution of lymphocyte membrane ganglioside GM1. Nature 257: 103-106.

Saida, K., T. Saida, C. R. Alving, M. J. Brown, D. H. Silberberg, and A. K. Asbury (1979) In vivo demyelination produced by purified antibodies to galactocerebroside. J. Neuropathol. Exp. Neurol. 38: 338.

Schroit, A. J., and R. E. Pagano (1978) Introduction of antigenic phospholipids into the plasma membrane of mammalian cells: Organization and antibody-induced lipid redistribution. Proc. Natl. Acad. Sci. USA 75: 5529-5533.

Sedlacek, H. H., J. Stourk, F. R. Seiler, W. Ziegler, and H. Wiegandt (1976) Cholera toxin induced redistribution of sialoglycolipid receptor at the lymphocyte membrane. FEBS Lett. 61: 272-276.

Sela, B.-A., A. Raz, and B. Geiger (1978) Antibodies to ganglioside GM1 induce mitogenic stimulation and cap formation in rat thymocytes. Eur. J. Immunol. 8: 268-274.

Sergott, R. C., M. J. Brown, and D. H. Silberberg (1982) Antiserum to galactocerebroside demyelinates guinea pig optic nerve in vivo. Neurology 32: 85 .

Sharon, F. J., and C. W. M. Grant (1978) A model for ganglioside behavior in cell membranes. Biochim. Biophys. Acta 507: 280-293.

Spiegel, S., S. Kassis, M. Wilchek, and P. H. Fishman (1984) Direct visualization of redistribution and capping of fluorescent gangliosides on lymphocytes. J Cell Biol. 99: 1575-1581.

Stern, P. L., and M. S. Bretscher (1979) Capping of exogenous Forssman glycolipid on cells. J. Cell Biol. 82: 829-833.

Storrie, B., and P. Edelson (1977) Distribution and capping of concanavalin A in fibroblasts: Direct endocytosis versus surface capping. Cell 11: 707-717.

Taylor, R. B., W. P. H. Duffus, M. C. Raff, and S. dePetris (1971) Redistribution and pinocytosis of lymphocyte surface immunoglobulin molecules induced by anti-immunoglobulin antibody. Nature 233: $225-229$.

Thompson, T. E., and T. W. Tillack (1985) Organization of glycosphingolipids in bilayers and plasma membranes of mammalian cells. Annu. Rev. Biophys. Chem. 14: 361-386.

Triarhou, L. C., M. Del Carro, and R. M. Herndon (1985) Ultrastructural evidence for phagocytosis by oligodendroglia. Neurosci. Lett. 53: 185-189.

Turner, R. J., J. Thompson, S. Sariban-Sohraby, and J. S. Handler (1985) Monoclonal antibodies as probes of epithelial membrane polarization. J. Cell Biol. 101: 2173-2180.

Ulmer, J. B., A. M. Edwards, F. A. McMorris, and P. E. Braun (1987) Cyclic AMP decreases the phosphorylation state of myelin basic proteins in rat brain cell cultures. J. Biol. Chem. 262: 1748-1755.

Wileman, T., C. Haring, and P. Stahl (1985) Receptor-mediated endocytosis. Biochemistry 232: 1-4. 